Research Article

\title{
Three-Dimensional Physical Simulation and Control Technology of Roof Movement Characteristics in Non-Pillar Gob-Side Entry Retaining by Roof Cutting
}

\author{
Xinzhu Hua, Guanfeng Chang $\mathbb{D}^{D}$, Xiao Liu, Bingjun Sun $\mathbb{D}^{D}$, Sen Yang, Enqian Wang, \\ and Chen Li
}

State Key Laboratory of Mining Response and Disaster Prevention and Control in Deep Coal Mines, Anhui University of Science and Technology, Huainan 232001, Anhui, China

Correspondence should be addressed to Guanfeng Chang; 1508009402@qq.com

Received 20 April 2021; Accepted 18 June 2021; Published 29 June 2021

Academic Editor: chao xu

Copyright (c) 2021 Xinzhu Hua et al. This is an open access article distributed under the Creative Commons Attribution License, which permits unrestricted use, distribution, and reproduction in any medium, provided the original work is properly cited.

\begin{abstract}
An overlying rock structure plays a key role in controlling the roof deformation of nonpillar gob-side entry retaining by roof cutting. On the bases of the actual geological conditions of II 632 Haulage Roadway at the Hengyuan coal mine, a similar threedimensional simulation experiment of roof precutting is conducted. Thereafter, the caving characteristics and migration law of the roof strata in the strike and dip directions are obtained. Moreover, the roof of the retained roadway and key strata of the goaf can form a hinge structure of the key blocks. By monitoring the deformation of the surrounding rock and stress distribution of the roof, the skew deformation characteristics of roadway roof are obtained. By observing the borehole peeping technology, the roof subsidence near the goaf is determined to be greater than that of the solid coal side, and the roof subsidence of the gob-side entry retained by roof cutting is greater than that of the floor heave and two sides approaching. Results of the three-dimensional similar simulation experiment indicate that the mechanical structure model of the key block of the retained roadway roof is constructed, and the mechanical analytical solution of the required support resistance of the retained roadway roof is obtained. This study proposes the constant resistance and large deformation anchor cable reinforcement support method to control the roof deformation of the retaining roadway. Through engineering application, the maximum value of the roof and floor movement of the retained roadway is stable at approximately $650 \mathrm{~mm}$. The retained roadway can meet the demand of the next mining face.
\end{abstract}

\section{Introduction}

Nonpillar gob-side entry retaining by roof cutting mining is one of the key technologies for safe and efficient coal production in China. The application of this technology can effectively improve the recovery rate of coal resources and alleviate the shortage of coal resources [1-4]. In actual mining activities, overburden movement has a substantial effect on the roof of roadway; the disturbance range of the overburden breaking and falling is large, thereby resulting in considerable roof deformation in the process of retaining roadway [5-7].

Numerous Chinese scholars have conducted research to solve the problem of roof stability control of the gob-side entry retaining by roof cutting without coal pillar. Zhang et al. [8] analyzed the roof fracture structure and its movement and deformation law of gob-side entry retaining by roof cutting and established the fracture mechanics model of a bilateral cantilever beam of the lower cutting slit and upper bending crack. Su et al. [9] studied the mechanism of roof cutting and pressure relief in the gob-side roadway (GR) in deep coal mine, and the overburden structure and migration law of GR in deep coal mine have been studied. Wang et al. [10] studied the entire process of overburden movement of self-formed roadway by roof cutting and pressure releasing through physical simulation test and determined that, through roof presplitting and cutting joints, the surrounding rock pressure of the roadway can be 
effectively relieved, thereby controlling the surrounding rock deformation. Zhang et al. [11] analyzed the disturbance factors during the period of "mining-retaining-using," through numerical simulation and on-site measurement; the stress and deformation characteristics of the surrounding rock during the reuse of the self-formed roadway were analyzed comprehensively. He et al. [12-14] used the mechanism of roof presplitting and pressure releasing at the goaf side as basis to establish the mechanical model of "surrounding rock structure-roadway side support body" under different roof positions. They also proposed surrounding rock control technologies, such as shaped-charge presplitting blasting, constant resistance large deformation anchor cable, and dense single pillar beside roadway.

Hua et al. [15] analyzed the fracture mechanism of basic roof presplitting blasting, established the fracture criterion based on tensile strength, and determined the minimum quantitative relationship between charge length and hole spacing when basic roof presplitting blasting was formed. Yang et al. [16] took coal mining in Shen Fu and Dongsheng coal mining areas as the engineering background; the roof deformation laws and mechanism in the process of gob-side entry by roof cutting were comprehensively studied by means of theoretical analysis, numerical simulation, and field test. Wang et al. [17] explored the mine pressure behavior characteristics of roadway under the condition of the gob-side entry retaining by roof cutting, a structural mechanics model, where "load-bearing structure" and "loadreleasing structure" are established and analyzed. Zhang and Han [18] proposed the concept of composite load-bearing structure of gob-side entry retaining, in which roof pressure is shared by the roof, wall, and floor. Gao and Guo [3] and $\mathrm{Ma}$ and $\mathrm{He}$ [19] analyzed the evolution law and mechanical mechanism of the surrounding rock structure of gob-side entry retaining based on the mechanical mechanism of the nonpillar gob-side entry retaining by roof cutting. To study the deformation mechanism of the filling body in the goaf side, Sun et al. [20] used key block theory as basis to establish the mechanical model of the basic roof fracture structure of the retaining roadway. The preceding research also analyzed the influence of the cutting angle and cutting height on the roof support resistance of the retaining roadway. Sun and Zhang [21] analyzed the deformation and failure characteristics of the surrounding rock and established the mechanical damage model of goaf support based on Coulomb Earth pressure theory. Wang et al. [22] introduced the roof presplitting blasting technology of gob-side entry retaining by roof cutting, the technology of forming support column by caving gangue along the goaf, and the concept of automatically forming the gob-side entry by roof collapse.

Guo et al. [23] deduced the relationship between the cutting angle and cutting height by establishing the mechanical model of the overburden structure. They also determined the reasonable parameters of the precrack roof cutting using a numerical calculation method. Guo et al. [24] studied the interaction relationship among roof bolt, tray, and bolt through numerical simulation and field combination. Sun et al. [25] determined that the key parameters affecting gob-side entry retaining in thin coal seam are presplitting cutting height, presplitting cutting angle, and the distance between presplitting blasting holes by analyzing the roof stress state in the process of thin coal seam mining. Based on the principle of gob-side entry retaining technology, Chen et al. [26] deeply studied the pressure relief effect, surrounding rock stress evolution law, and control technology of deep gob-side entry retaining technology. Yuan et al. [27] studied the reasonable parameters of gobside entry retaining by roof cutting in the face of fully mechanized mining with thin direct roof and large mining height by combining theoretical analysis, numerical simulation, and field monitoring.

The preceding studies have indicated the extensive achievements in the research of roof structure, roof cutting parameters, and supporting force of gob-side entry retaining by roof cutting. However, only a few studies have been conducted on the interaction between the roof structure of roof gob-side entry retaining by roof cutting and the overall movement of the overlying strata. In addition, a two-dimensional plane model is often used in physical experiments, and the actual underground activities are in three-dimensional space. A three-dimensional model is used to study a physical simulation experiment platform, which can objectively reflect the movement characteristics of the overlying rock of the retaining roadway. Therefore, this research takes the II 632 haulage drift of the Hengyuan coal mine as an example. By conducting a three-dimensional similar simulation physical experiment, the roof structure characteristics and overlying rock movement law under the two dimensions of strike and dip are studied. On the bases of the deformation characteristics of the retaining roadway roof, the mechanical structure model of the key block of the retaining roadway roof is constructed, and the mechanical analytical solution of the retaining roadway roof supporting resistance is obtained. This study proposes the method of constant resistance and large deformation anchor cable reinforcement support to control the roof deformation of retaining roadway. Field application shows that the effect of roadway retaining is good. Moreover, the research results can provide a theoretical basis and reference value for the roof stability control of gob-side entry retaining by roof cutting.

\section{Experimental Scheme}

2.1. Project Overview. The average thickness of coal seam in the II 632 working face of the Hengyuan coal mine is $3 \mathrm{~m}$, length of the working face is $185 \mathrm{~m}$, strike length is $1725.3 \mathrm{~m}$, and elevation is from $-662 \mathrm{~m}$ to $-709 \mathrm{~m}$. The elevation of the return air channel from the ground is from $-596 \mathrm{~m}$ to $-760 \mathrm{~m}$, elevation of the transport channel from the ground is from $-637 \mathrm{~m}$ to $-778 \mathrm{~m}$, and roadway section is $5.2 \mathrm{~m} \times 2.6 \mathrm{~m}$. The direct roof of the working face is from $2.25 \mathrm{~m}$ to $4 \mathrm{~m}$ dark gray mudstone, basic roof is from $2 \mathrm{~m}$ to $4 \mathrm{~m}$ thick light gray fine sandstone, direct bottom is from $0.4 \mathrm{~m}$ to $1.7 \mathrm{~m}$ thick gray or gray black mudstone, and old bottom is from $7.09 \mathrm{~m}$ to $17.10 \mathrm{~m}$ thick sandstone. The rock mechanical parameters 
of the roof and floor of the coal seam are shown in Table 1, and the comprehensive histogram is shown in Figure 1.

2.2. Model Experiment Scheme Design. The three-dimensional stress model is adopted in this similarity simulation test. And, the experimental process is as follows.

(1) The model size is $1100 \mathrm{~mm} \times 1000 \mathrm{~mm} \times 1000 \mathrm{~mm}$, simulation cutting angle is $15^{\circ}$, cutting height is $8 \mathrm{~m}$, and the iron wire with a similarity ratio of $1: 100$ is used to simulate the bolt and anchor cable (see Figure 2)

(2) The simulated bolt diameter is $20 \mathrm{~mm}$, length is $2400 \mathrm{~mm}$, anchor cable diameter is $17.8 \mathrm{~mm}$, and length is $6200 \mathrm{~mm}$

(3) The long wood bar is used to simulate the coal seam mining, and one wood bar is drawn out each time to simulate coal mining

(4) Rock layers with different lithology in the model are made and laid by water, gypsum powder, fine river sand, and barite powder with different proportions; moreover, the rock specimens with different proportions meet the specified strength and weight requirements through indoor rock mechanics tests

(5) During the experiment, according to the rock stratum size of the experimental model, the floor rock stratum was laid first

(6) The laying of coal seam is replaced by wooden bars, and the coal seam excavation is carried out by extracting the wooden bars; the specification of each wooden bar is $L \times B \times H=1000 \mathrm{~mm} \times 50 \mathrm{~mm} \times$ $30 \mathrm{~mm}$

(7) When laying the test model, the thin plastic sheet is embedded in advance to cut the seam in the roadway roof, the angle between the plastic sheet and the vertical direction is $15^{\circ}$, and the size of plastic sheet is $L \times B=1000 \mathrm{~mm} \times 80 \mathrm{~mm}$

(8) The strata above the coal seam are laid in order according to the size of the model, during the laying process, the angle of the plastic shall not change, and this method is used until the end of the laying of the overlying strata

(9) When the model is stationary for about 10 days, the outer baffle of the model will be removed when the excavation requirements are met

(10) The model surface is coated with white coating, the displacement observation line and displacement observation point are arranged, the strain gauge and strain gauge are connected, and the data terminal is debugged, and then the next excavation experiment is carried out

(11) Each time along the strike of the working face, a wooden bar is drawn out to simulate the mining of a knife of coal, a total of 20 knives are mined, that is, the working face is pushed forward for $100 \mathrm{~m}$, and each knife is allowed to stand for $2 \mathrm{~h}$
(12) A group of strain gauges are embedded at the direct roof $40 \mathrm{~mm}$ above the roadway, and the spacing of each strain gauge is $200 \mathrm{~mm}$, as shown in Figure 3; the stress change of the roof of the retained roadway during the mining process is observed

\section{Movement Law of the Overlying Strata in Stope}

3.1. Movement Law of Overburden in the Working Face along Incline. When the working face advances $10 \mathrm{~m}$, as shown in Figure 4(a), a small amount of roof subsidence began to appear above the roadway, bed separation fissures appeared at $4 \mathrm{~m}$ and $8 \mathrm{~m}$ above the direct roof of the coal seam, and the basic roof was in a stable state. When the working face is advanced to $20 \mathrm{~m}$, as shown in Figure 4(b), the direct roof strata over the goaf collapses, and the roof of the key block at the cutting slit side of the roadway collapses along the reserved roof cutting line, thereby cutting off the physical connection between the roof above the roadway and the roof of the goaf. Furthermore, the roof of the roadway and roof of the goaf lose the mechanical constraints.

When the working face is advanced to $45 \mathrm{~m}$, as shown in Figure 4(c), the reserved cutting joint developed and expanded upward. Vertical microcracks appear near the cutting slit, and the gangue in the goaf is gradually compacted in the movement of the overlying strata. The goaf tends to produce a large area of arch fracture, and evident separation layer appears above the basic roof. A relatively stable rock block hinge structure is formed above the retained roadway, and the stable hinge structure plays an important role in the process of controlling the roof stability of the retained roadway.

When the working face is advanced to $80 \mathrm{~m}$, as shown in Figure 4(d), the goaf is further compacted under the action of the dead weight of the roof rock and the bearing pressure. Moreover, the separation value of the upper strata decreases, and the roof shows evident bending and subsidence deformation, thereby forming a bending zone. Lastly, the vertical cracks continue to develop at the upper strata.

The process of coal seam mining is simulated. In the process of coal seam mining, close range photography is used to monitor the activity of the overlying strata. Four groups of measuring points are set at heights of $4 \mathrm{~m}, 8 \mathrm{~m}$, $13 \mathrm{~m}$, and $18 \mathrm{~m}$ of the coal seam roof. The roof subsidence curves of the different layers are shown in Figure 5.

When the working face is advanced by $20 \mathrm{~m}$, the direct roof collapses for the first time. At the initial stage of the working face, the roof subsidence is small, mining activities have minimal influence on the movement of the overlying strata, displacement changes gradually, and the displacement curve trend is trough-shaped. At the level of $4 \mathrm{~m}$ height of the coal seam roof, the roof collapses between $10 \mathrm{~m}$ and $50 \mathrm{~m}$ away from the open-off cut, and the maximum subsidence is $2.5 \mathrm{~m}$.

When the working face is advanced $45 \mathrm{~m}$, as shown in Figure 6, the direct roof of the working face completely collapses. From the roof subsidence change of the working face, the roof of the No. 6 coal seam collapses between $10 \mathrm{~m}$ 
TABLe 1: Mechanical properties of rock.

\begin{tabular}{cccccc}
\hline & Lithology & Uniaxial compressive strength (MPa) & Uniaxial tensile strength (MPa) & Cohesion (MPa) & Poisson's ratio \\
\hline \multirow{2}{*}{ Roof } & Mudstone & 28.4 & 0.95 & 4.72 & 0.2 \\
& Fine sandstone & 112.1 & 5.71 & 7.27 & 0.14 \\
\hline \multirow{2}{*}{ Floor } & Mudstone & 28.5 & 0.97 & 5.07 & 0.21 \\
& Fine sandstone & 112.5 & 4.62 & 7.88 & 0.13 \\
\hline
\end{tabular}

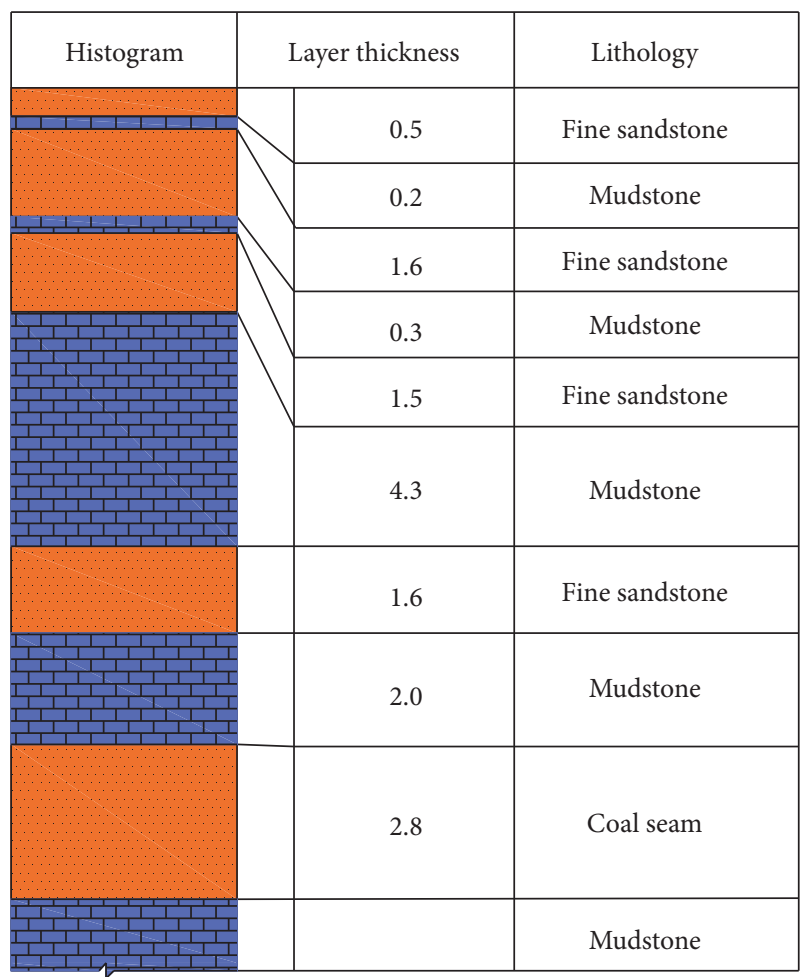

Figure 1: Comprehensive histogram.

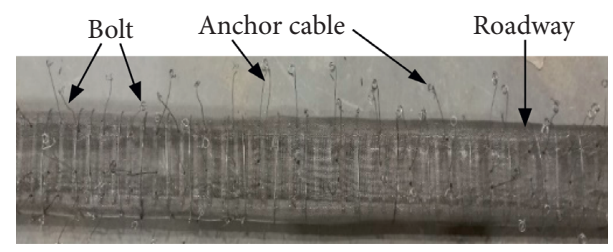

Figure 2: Roadway model diagram.

and $50 \mathrm{~m}$ away from the cut hole at $4 \mathrm{~m}$ height. Furthermore, the maximum subsidence is approximately $2.8 \mathrm{~m}$.

\subsection{Movement Law of the Overlying Rock along the Strike of the} Working Face. Figure 7 shows that when the working face is advanced by $20 \mathrm{~m}$, the roof of the goaf is suspended, and the area of the direct roof above the working face is gradually increased. When the working face is advanced to $30 \mathrm{~m}$, cracks appear in the roof $5 \mathrm{~m}$ and $8 \mathrm{~m}$ above the coal seam. Moreover, the roof of the goaf lagging behind the temporary support area begins to sink gradually. When the working face is advanced $45 \mathrm{~m}$, the immediate roof above the goaf collapses for the first time, the roof caving height is $7 \mathrm{~m}$, and the caving step distance is $40 \mathrm{~m}$. Cracks in the upper strata of the basic roof further develop and expand, and these cracks evidently show a trend of expansion. When the working face advances $80 \mathrm{~m}$, the roof shows a second large-area collapse phenomenon, and the collapse occurs $20 \mathrm{~m}$ above the basic roof, which is an arch fracture. As the working face continues to advance, square collapse occurs, the roof subsidence deformation is severe, and the horizontal roof falling strata are hinged with each other, thereby forming a masonry beam structure. When the working face advances $100 \mathrm{~m}$, the broken gangue in the goaf is further compacted, and the caving layer of the overlying strata in the goaf roof gradually increases.

Figure 8 shows that when the coal seam is advanced to $45 \mathrm{~m}$ along its strike direction, the roof is broken at $8 \mathrm{~m}$ above the coal seam $20 \mathrm{~m}$ to $40 \mathrm{~m}$ away from the open-off cut. The maximum subsidence of the roof occurs $4 \mathrm{~m}$ above the coal seam and $50 \mathrm{~m}$ away from the open-off cut, and the maximum subsidence is approximately $1.8 \mathrm{~m}$. There is no evident roof subsidence at the $13 \mathrm{~m}, 18 \mathrm{~m}$, and $23 \mathrm{~m}$ strata overlying the stope. When the working face is advanced $85 \mathrm{~m}$, a large area of caving occurs in the working face, and the roof subsidence above the coal seam decreases gradually with an increase in the seam position. The maximum amount of the lower layer $60 \mathrm{~m}$ away from the open-off cut is $2.6 \mathrm{~m}$. The displacement changes gradually in the middle of the goaf. From $75 \mathrm{~m}$ to $85 \mathrm{~m}$ away from the open-off cut, the overburden of the working face forms an articulated structure above the goaf, thereby slowing down the overburden subsidence. Lastly, the maximum subsidence is approximately $1.5 \mathrm{~m}$.

\subsection{Deformation Characteristics of the Roadway Surrounding} Rock. The borehole peeper is placed $20 \mathrm{~m}$ away from the open-off cut in the roadway to observe the internal deformation of the surrounding rock of the retained roadway (see Figure 9). When the working face is advanced to $20 \mathrm{~m}$, roof subsidence occurs near the goaf, and the floor heave is negligible. When the working face is advanced to $45 \mathrm{~m}$, the roof subsidence near the goaf is evident. When the working face is advanced to $80 \mathrm{~m}$, the maximum roof subsidence is approximately $10 \mathrm{~mm}$, showing skew deformation, and the roof subsidence near the goaf is greater than that of the coal pillar side. During the mining period, the roof subsidence of the gob-side entry retaining by roof cutting is greater than that of the floor heave and roadway wall approaching.

3.4. Distribution Law of the Roadway Roof Stress. Through the embedded strain gauge, the roof stress change above the roadway is obtained, as shown in Figure 10. When it is $20 \mathrm{~m}$ to $40 \mathrm{~m}$ ahead of the working face, stress increases 


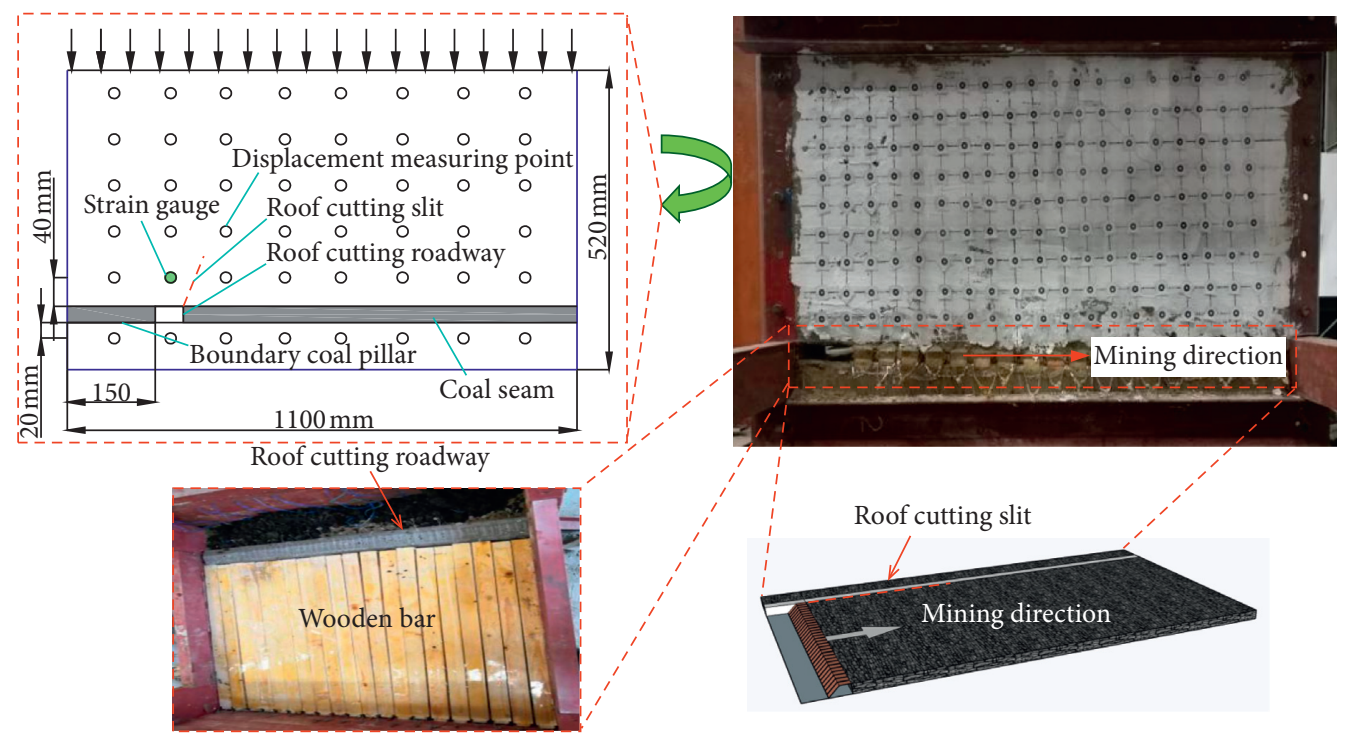

FIgURE 3: Layout of the coal seam excavation and measuring points.

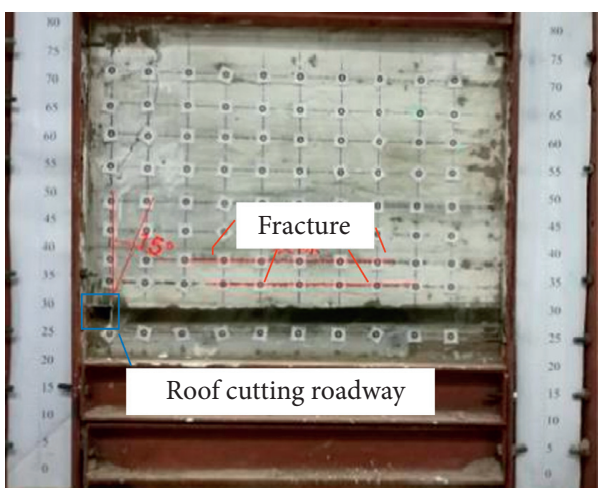

(a)

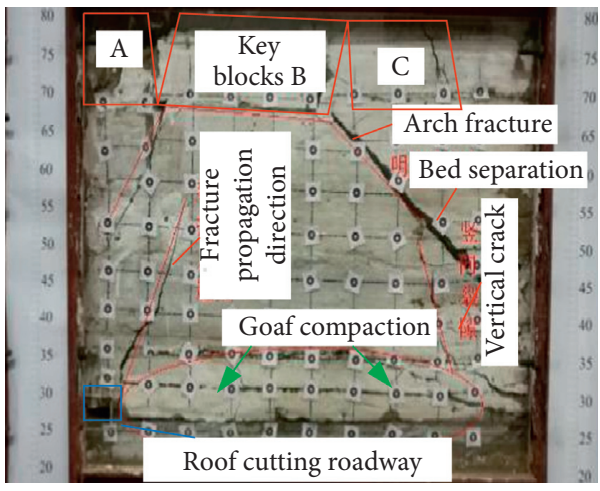

(c)

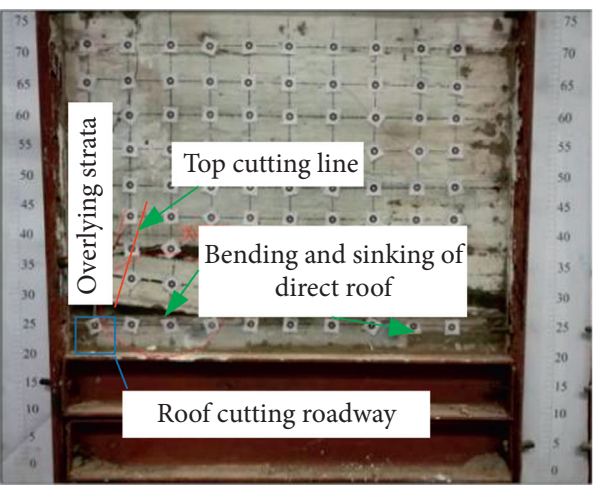

(b)

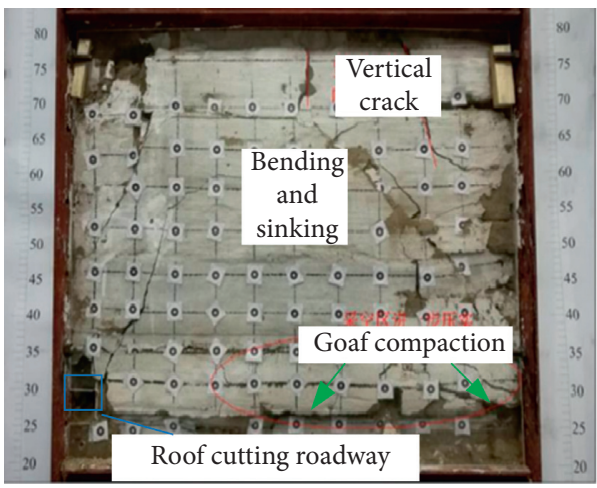

(d)

Figure 4: Dip excavation of the coal seam. Coal seam excavation: (a) $5 \mathrm{~m}$; (b) $20 \mathrm{~m}$; (c) $45 \mathrm{~m}$; (d) $80 \mathrm{~m}$.

substantially. At approximately $20 \mathrm{~m}$ away from the working face, the roof stress of the roadway reaches the peak value, which is the influence area of the one-time mining ahead. The results show that the mining stress from $50 \mathrm{~m}$ to $80 \mathrm{~m}$ ahead of the working face tends to be gentle, and the fluctuation range of the stress is small. Hence, the gentle area is affected by the first mining advance. Moreover, the results show that the stress of $0-10 \mathrm{~m}$ lagging working face 


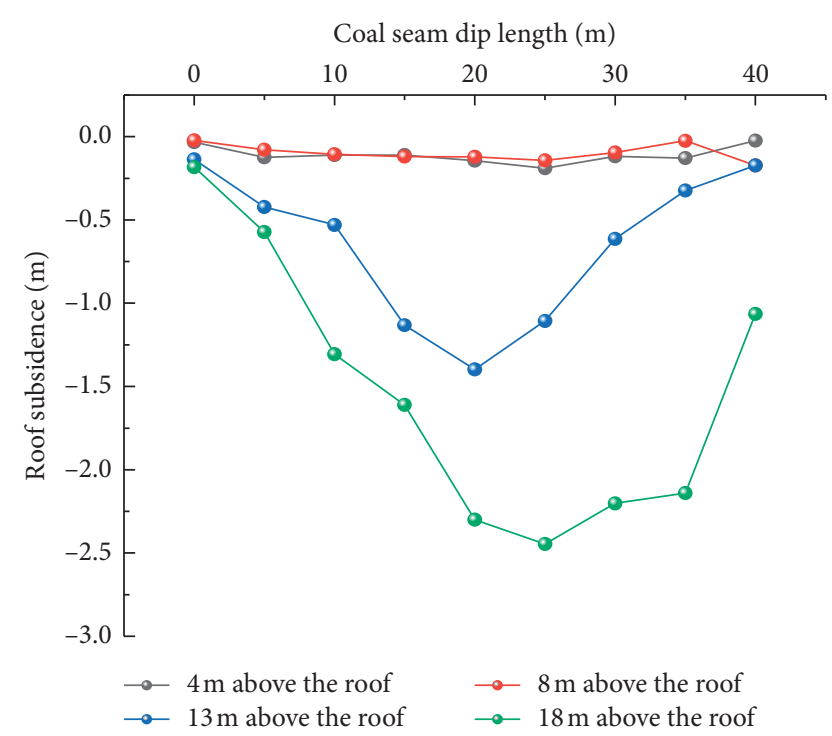

FIGURE 5: Displacement curve of the roof measuring point after mining $(20(\mathrm{~m}))$.

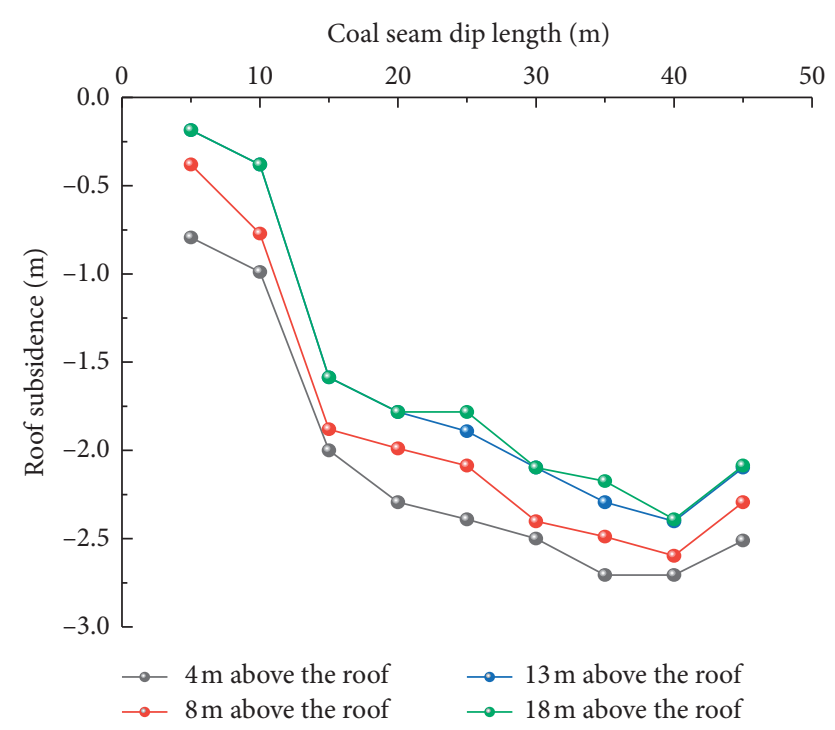

FIgURE 6: Roof displacement monitoring chart.

decreases, whereas that of 10-60 m lagging working face increases. Note that the distance of lagging working face is from $20 \mathrm{~m}$ to $60 \mathrm{~m}$ due to the influence of one-time mining.

\section{Mechanical Analysis of the Hinge Key Block for Roof Cutting and Pressure Releasing}

According to the law of overburden breaking and migration analyzed by the three-dimensional similar simulation experiment, the roof of the retained roadway is fractured on the side of the solid coal, and the roof of the gob-side entry retaining overall produced rotary subsidence. Hence, the hinge structure of the key block is formed, which jointly carries the load of the overlying strata. After the roof of the retaining roadway rotates and sinks, the hinge structure of the key block formed by the roof of the retaining roadway and support resistance of the surrounding rock of the retaining roadway form a stable structure together, thereby forming a stable structure, as shown in Figure 11. In this figure, $F_{s}$ is the supporting force of the solid coal side, $\mathrm{kN}$; Fm is the supporting resistance of the roadway, $\mathrm{kN} ; F_{g}$ is the supporting force of the gangue, $\mathrm{kN} ; \mathrm{x}_{0}$ is the plastic zone range of solid coal side, $\mathrm{m}$; $\mathrm{B}$ is the width of the roadway, $\mathrm{m}$; $\mathrm{a}$ is the action range of gangue supporting force, $\mathrm{m}$; $h$ is the height of the coal seam, $\mathrm{m} ; \mathrm{h}_{f}$ is the height of immediate roof, $\mathrm{m}$; $h_{\mathrm{d}}$ is the cutting height, $\mathrm{m} ; \beta$ is the cutting angle, ${ }^{\circ} ; L_{i}$ is the breaking length of the key block $\mathrm{B}, \mathrm{m} ; \mathrm{F}_{h}$ is the weight of the direct roof and key block B; and $\theta$ is the turning angle of the key block B.

4.1. Ultimate Breaking Length of Key Block B $L_{i}$. Theory of broken line states that when the goaf beside the retained roadway is periodically collapsed, the broken length of the key block above the retained roadway roof $L_{i}$ is as follows [28]:

$$
L_{\mathrm{i}}=1\left(-\frac{l}{S}+\sqrt{\frac{l^{2}}{S^{2}}+\frac{3}{2}}\right)
$$

where $S$ is the length of the working face, $\mathrm{m}$, and $L$ is the basic jacking step, $\mathrm{m}$.

4.2. Supporting Force of Goaf of the Gangue on Key Block $F_{g}$. When the long cantilever is cut off to form a short cantilever, in the process of the key block B of the retained roadway roof turning and sinking and with the continuous compaction of the gangue contacting with the retaining roadway roof, the compression of gangue in the goaf under the rotation of key block B is $\triangle u$. The entire key block B forms the hinged pressure bearing structure of the key block from the start of sinking to the release of sinking. The supporting force $F_{g}$ of the gangue per unit area in the goaf is as follows [28]:

$$
\begin{aligned}
& f_{g}=K_{g} \Delta u, \\
& \Delta u=\frac{h_{f}\left(K_{s}-K_{c}\right)}{\tan \theta},
\end{aligned}
$$

where $K_{g}$ is the support coefficient of the caving gangue, $\mathrm{MPa} / \mathrm{m} ; K_{c}$ is the residual crushing expansion coefficient of the collapsed gangue after compaction, which can be determined according to the simulation test or field measurement; $K_{s}$ is the crushing expansion coefficient of the roof rock; $h_{f}$ is the direct roof height, $\mathrm{m}$; and $\theta$ is the rotation angle of the retained roadway roof.

Thereafter, according to formula (1)-(3), the supporting force $F_{g}$ of the goaf gangue to the key block B is as follows:

$$
F_{g}=\int_{x_{0}+b}^{\left(L_{i} \cos \theta-x_{0}-b-h_{d} \tan \beta\right)} f_{g}\left[\left(x-\left(L_{i} \cos \theta-x_{0}-b\right)\right)\right] \mathrm{d} x .
$$

The expression of the limit equilibrium zone width $x_{0}$ of the coal body in the retaining roadway is as follows [12]: 


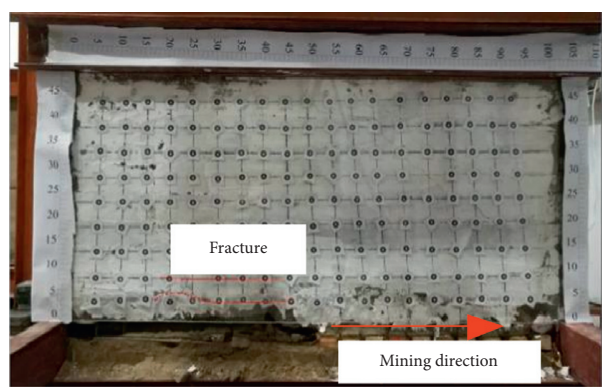

(a)

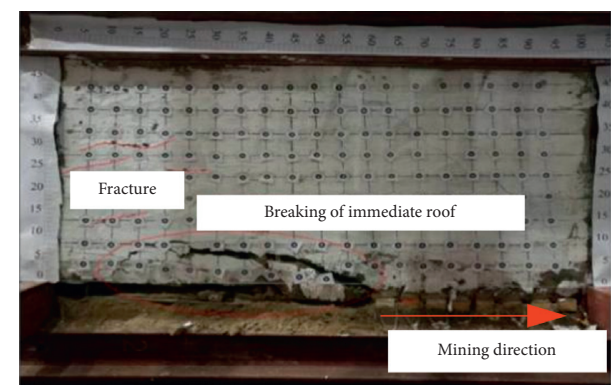

(b)

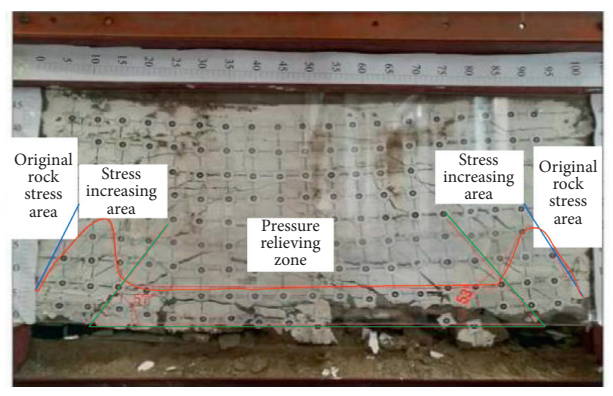

(c)

Figure 7: Excavation along the dip of the coal seam. Coal seam excavation: (a) $20 \mathrm{~m}$; (b) $45 \mathrm{~m}$; (c) $80 \mathrm{~m}$.

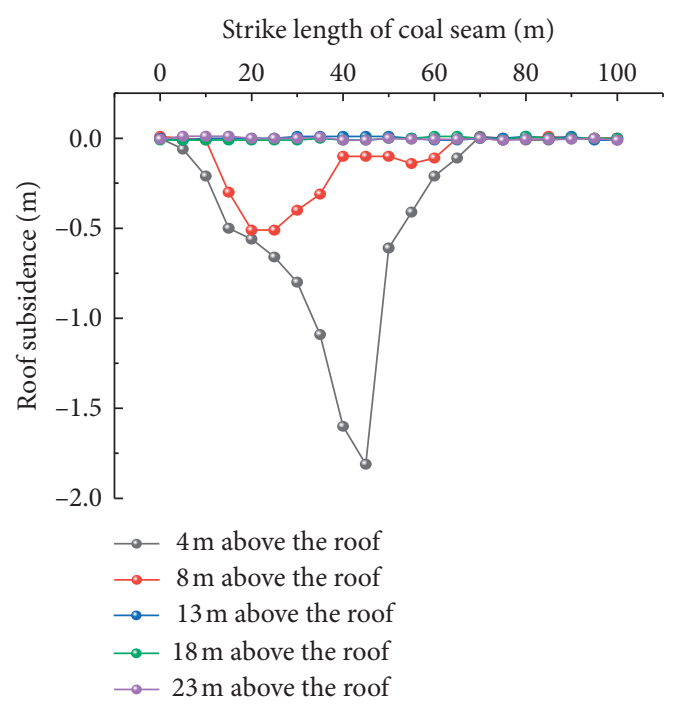

(a)

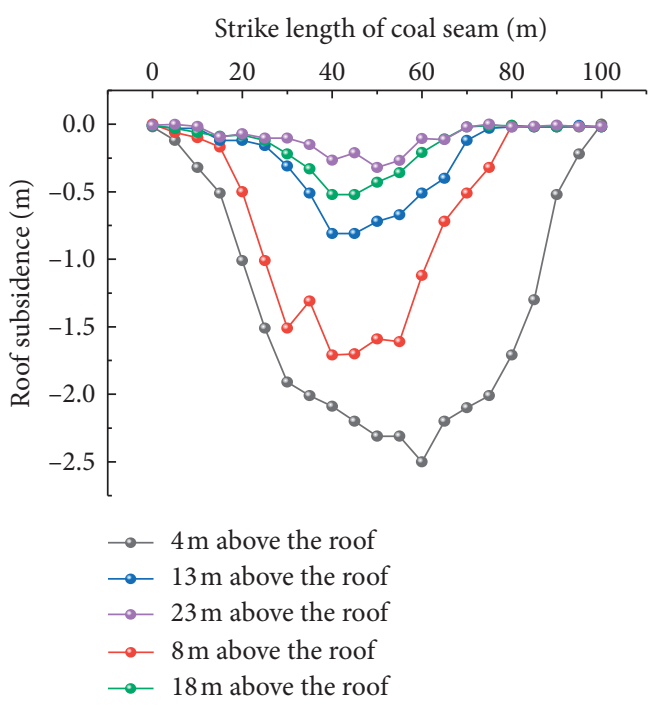

(b)

Figure 8: Displacement curve of the roof. Coal seam excavation: (a) $45 \mathrm{~m}$; (b) $85 \mathrm{~m}$.

$$
x_{0}=\frac{h A}{2 \tan \delta} \ln \left(\frac{k \gamma H+c_{0} / \tan \delta}{c_{0} / \tan \delta+p_{x} / A}\right) \text {, }
$$

where $A$ is the lateral pressure coefficient; $p_{x}$ is the support strength of the coal wall, $\mathrm{MPa} ; h$ is the buried depth of the roadway, $\mathrm{m} ; c_{0}$ is the bonding strength of coal and rock mass, $\mathrm{MPa} ; \delta$ is the friction angle in the coal body, ${ }^{\circ} ; \gamma$ is the average density of the overlying strata, $\mathrm{kN} / \mathrm{m}^{3} ; k$ is the stress concentration factor; and $h$ is the height of roadway, $m$.

4.3. Supporting Force of the Solid Coal Side $f_{s}$. Key block B produces the breaking position at the elastoplastic interface of the side coal retaining roadway. The supporting force $f_{s}$ of the solid coal on key blocks is as follows [29]: 


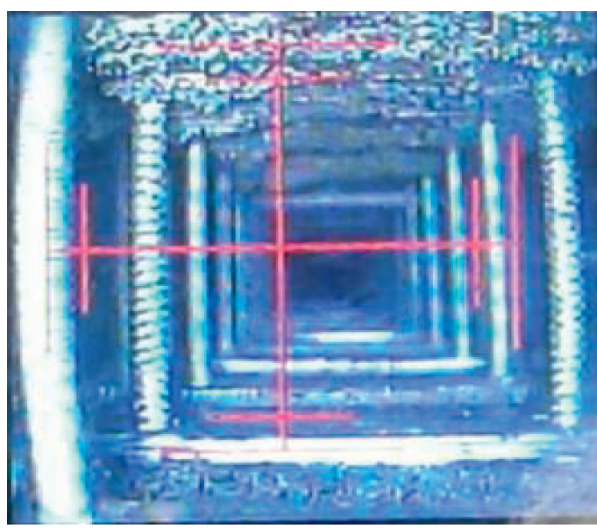

(a)

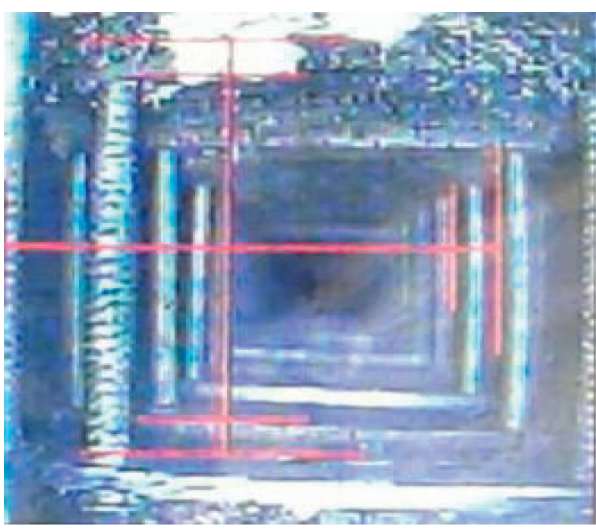

(c)

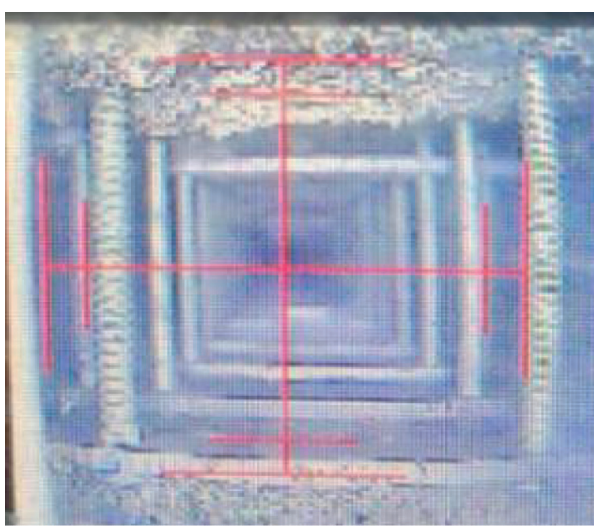

(b)

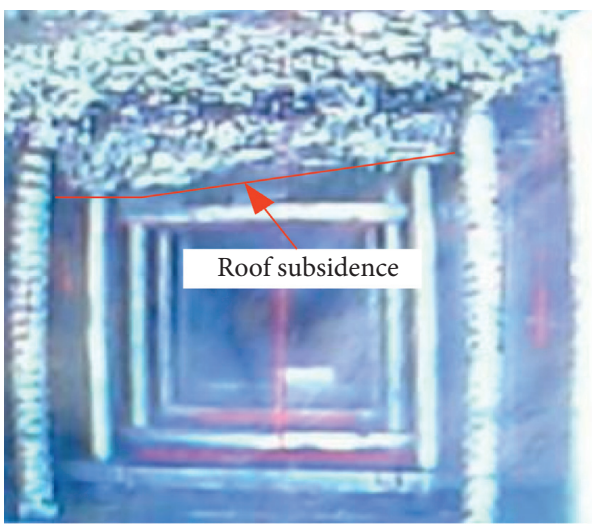

(d)

FIGURE 9: Roadway surrounding rock deformation at different forward distances. Coal seam excavation: (a) $0 \mathrm{~m}$; (b) $20 \mathrm{~m}$; (c) $45 \mathrm{~m}$; (d) $80 \mathrm{~m}$.

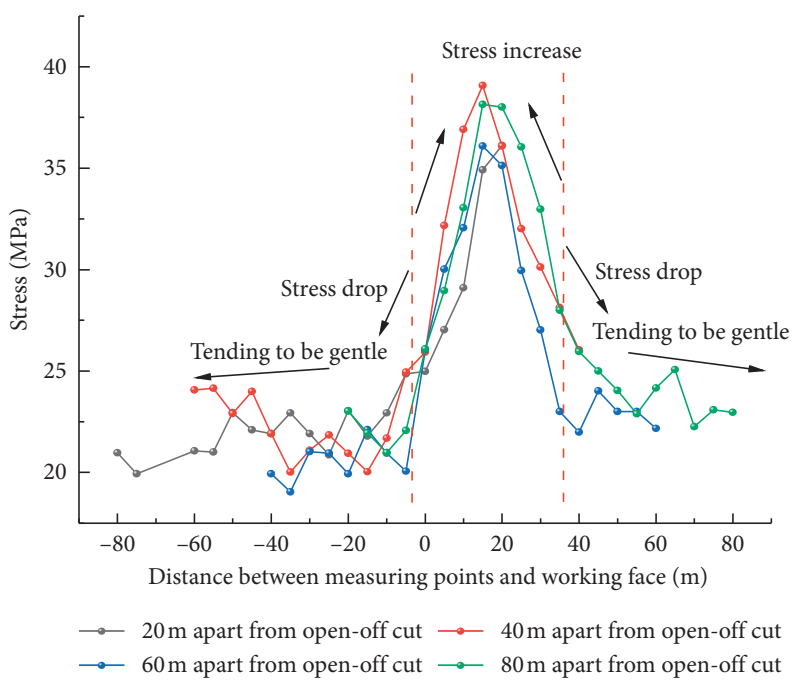

Figure 10: Stress curve of the roadway roof. 


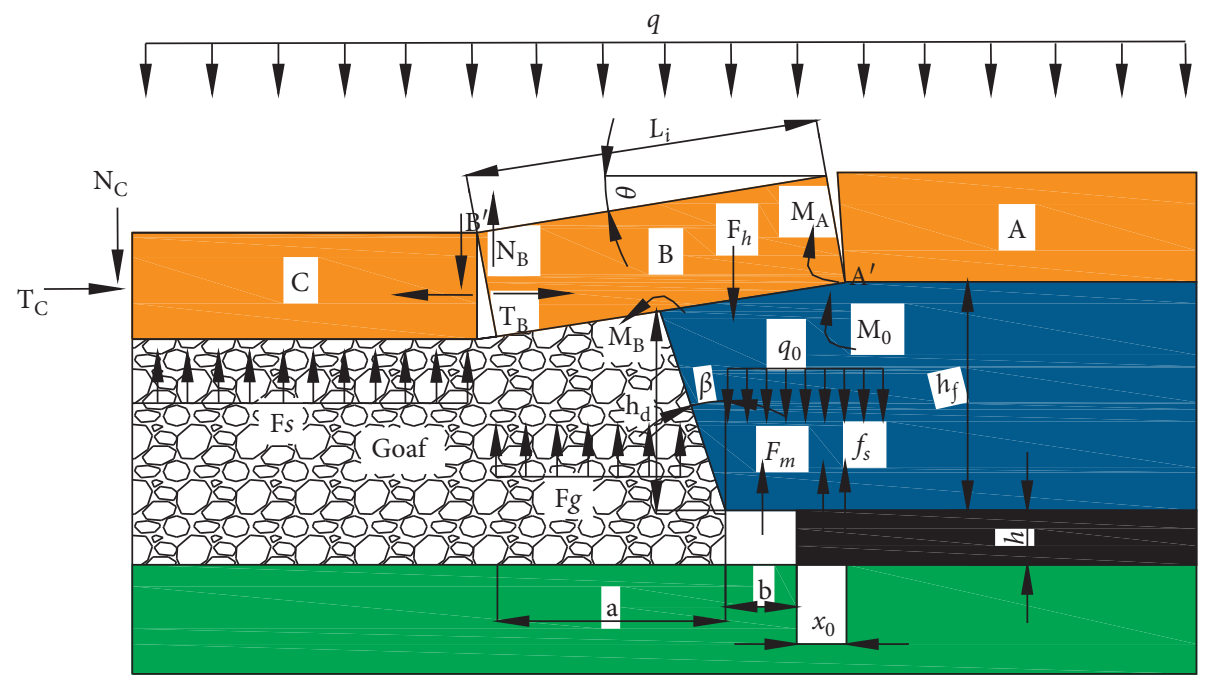

FIgURE 11: Mechanical model of the hinged rock block.

$$
f_{s}=\left(\frac{c_{0}}{\tan \varphi_{0}}+\frac{p_{x}}{A}\right) e^{\left(\frac{2 x \tan \varphi_{0}}{h A}\right)}-\frac{c_{0}}{\tan \varphi_{0}},
$$

where $\varphi_{0}$ is the internal friction angle of the interface between the top and bottom slate, .

4.4. Supporting Force of the Roadway Side Support. The horizontal thrust of key block B is as follows:

$$
T_{B}=\frac{q_{1} L_{i}}{2\left(h_{f}-\Delta u\right)},
$$

where $q_{1}$ is the weight per unit length of the basic roof and its load, $\mathrm{kN} ; h_{f}$ is the thickness of the basic roof, $\mathrm{m}$; and $\Delta u$ is the subsidence of rock block B at $\mathrm{B}^{\prime}, \mathrm{m}$.

The static balance method is used to analyze key block $\mathrm{C}$.

From the formula $\sum F_{\mathrm{x}}=0$,

$$
T_{B}=T_{C}
$$

From the formula $\sum \mathrm{F}_{\mathrm{y}}=0$,

$$
F_{\mathrm{s}}+N_{B}=N_{C}+q L_{\mathrm{i}} \text {. }
$$

From the formula $\sum M_{B^{\prime}}=0$,

$$
M_{B}+T_{C}\left(h_{f}-\Delta \mathrm{u}\right)+F_{\mathrm{s}} \frac{1}{2}-N_{C} \mathrm{l}-\frac{q 1^{2}}{2}=0 .
$$

The results are as follows:

$$
\begin{gathered}
N_{C}=\frac{M_{B}+T_{B}\left(h_{f}-\Delta \mathrm{u}\right)+F_{\mathrm{s}} 1 / 2-q 1^{2} / 2}{1}, \\
N_{B}=\frac{M_{B}+T_{B}\left(h_{f}-\Delta \mathrm{u}\right)+F_{\mathrm{s}} 1 / 2-q 1^{2} / 2}{1} .
\end{gathered}
$$

From the formula $\sum M_{A^{\prime}}=0$,

$$
\begin{aligned}
& M_{A}+M_{0}+\int_{0}^{x_{0}} f_{s}\left(x_{0}-x\right) \mathrm{d} x+F_{m}\left(x_{0}+\frac{b}{2}\right) \\
& \quad+F_{\mathrm{g}}\left(\frac{\mathrm{a}}{2}+\mathrm{x}_{0}+\mathrm{b}\right)+T_{B}\left(h_{f}-\Delta u\right)-M_{B}-\frac{q L_{i}^{2}}{2}-\frac{q_{0}\left(x_{0}+b\right)^{2}}{2}-N_{B} L_{\mathrm{i}}=0 .
\end{aligned}
$$

The results show that the support resistance of the roadway side is as follows:

$$
\mathrm{F}_{\mathrm{m}}=\frac{2 \mathrm{M}_{\mathrm{B}}+q L_{i}^{2}+q_{0}\left(x_{0}+b\right)^{2}+2 N_{B} L_{i}-2\left[F_{\mathrm{g}}\left(a / 2+x_{0}+b\right)+\int_{0}^{x_{0}} f_{s}\left(x_{0}-x\right) \mathrm{d} x+T_{B}\left(h_{f}-\Delta u\right)+M_{A}+M_{0}\right]}{2 x_{0}+b},
$$




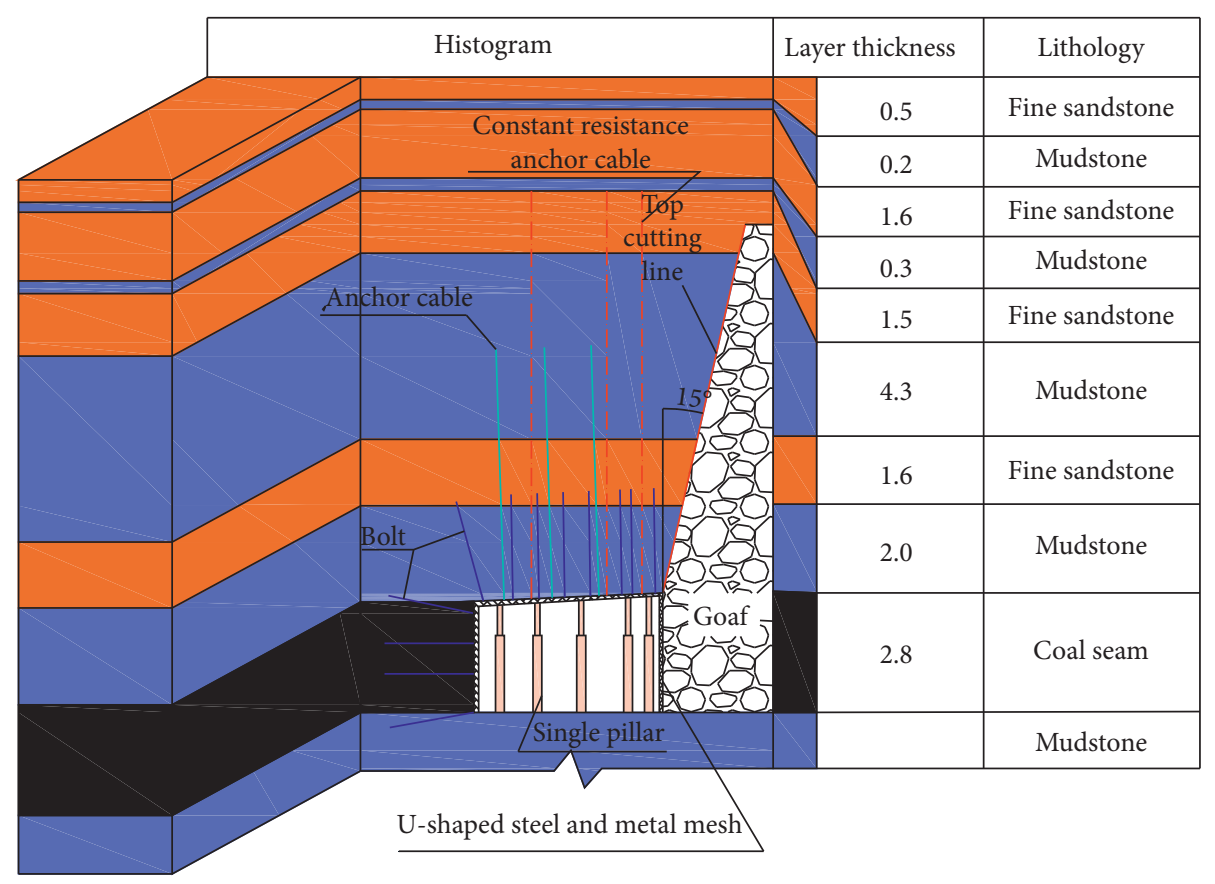

FIGURE 12: Diagram of the roadway section support.

where $F_{m}$ is the support resistance of the roadway.

Formula (13) shows that when the retaining roadway roof breaks at the solid coal side, the roof of retaining roadway is in a stable state under the action of its own structure and supporting force of solid coal wall side and active supporting resistance. Under the condition that the supporting force of retaining roadway roof structure and solid coal side is fixed, the roof deformation control is mainly realized by increasing the supporting resistance provided by anchor cable. Therefore, constant resistance and large deformation anchor cable is used to reinforce the roof of the retained roadway.

\section{Deformation Control of the Surrounding Rock in the Gob-Side Entry Retaining by Roof Cutting}

5.1. Support Parameters and Control Technology of the GobSide Entry Retaining by Roof Cutting. According to the results of three-dimensional similar simulation experiment and theoretical analysis, combined with the engineering background of II 632 working face in Hengyuan coal mine, the key technologies of active and passive strengthening support during roadway retaining are proposed, as shown in Figure 12. The roof is composed of a bolt with diameter of $\Phi 20 \mathrm{~mm}$, length of $2400 \mathrm{~mm}$, ribbed steel bar, spacing of $750 \mathrm{~mm}$, row spacing of $800 \mathrm{~mm}$, anchor cable diameter of $\Phi 17.8 \mathrm{~mm}$, length of $6200 \mathrm{~mm}$, spacing of $1300 \mathrm{~mm}$, row spacing of $1600 \mathrm{~mm}$, M3 steel strip, and $5.0 \mathrm{~m} \times 1.0 \mathrm{~m}$ steel mesh. In the mining advance affected area, constant resistance large deformation anchor cable support and single pillar support are added. The diameter of the constant resistance large deformation anchor cable is $\Phi 21.8 \mathrm{~mm}$ and length is $9500 \mathrm{~mm}$. Three rows are arranged. The distance between the constant resistance anchor cable on the cutting slit side and roof cutting line is $500 \mathrm{~mm}$ and the row distance is $1000 \mathrm{~mm}$. The distance between the second row of constant resistance anchor cable and roof cutting line is $1500 \mathrm{~mm}$ and row distance is $1600 \mathrm{~mm}$. The distance between the constant resistance anchor cable on the solid coal side and the coal wall is $1500 \mathrm{~mm}$ and row distance is $3200 \mathrm{~mm}$. Three rows of single pillars are arranged along the roadway section, and the advance support range is $40 \mathrm{~m}$. Two rows of single pillars are added $150 \mathrm{~m}$ behind the working face, and U-shaped steel and metal mesh are used as gangue retaining support at the side of the goaf. After the retaining roadway is stable, the single passive support is removed.

5.2. Analysis of the Roof Control Effect of the Gob-Side Entry Retaining by RoofCutting. To verify the roof control effect of nonpillar gob-side entry retaining by roof cutting, the deformation of the surrounding rock of the roadway retaining along the goaf $500 \mathrm{~m}$ in II 632 transportation chute was observed. Moreover, a survey station is arranged every $50 \mathrm{~m}$ in advance working face $100 \mathrm{~m}$; the roof and floor displacements were measured using the cross-shaped measuring point method. And five observation stations were arranged in the transportation chute to continuously observe the roadway deformation, as shown in Figure 13. The influence range of one mining advance is $42 \mathrm{~m}$, in which the deformation of roof and floor is considerably severe, the roof subsidence increases from $32 \mathrm{~mm}$ to $114 \mathrm{~mm}$, the floor heave increases from $30 \mathrm{~mm}$ to $102 \mathrm{~mm}$, and the roof and floor convergence increases from $52 \mathrm{~mm}$ to $216 \mathrm{~mm}$. The influence range of the roadway retaining by one time mining is 


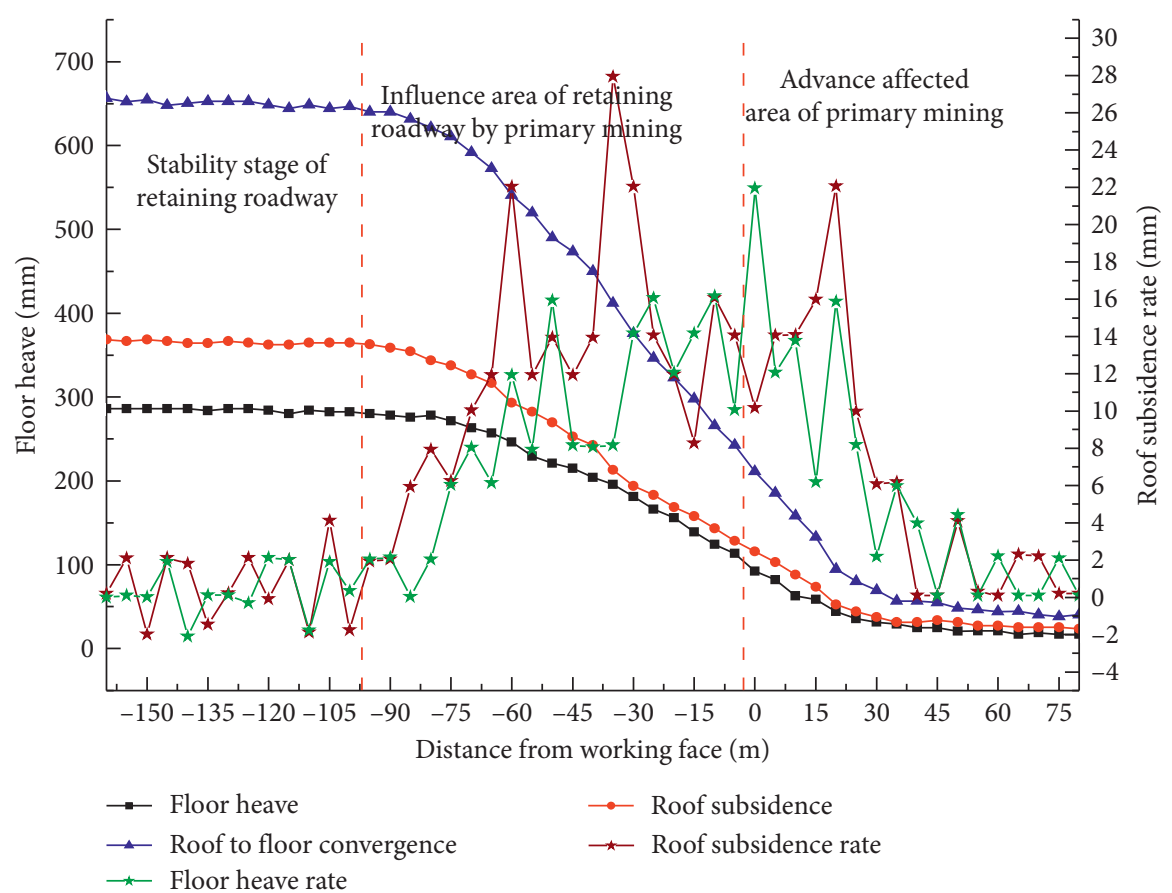

FIGURE 13: Deformation curve of the roof and floor of nonpillar gob-side entry retaining by roof cutting.

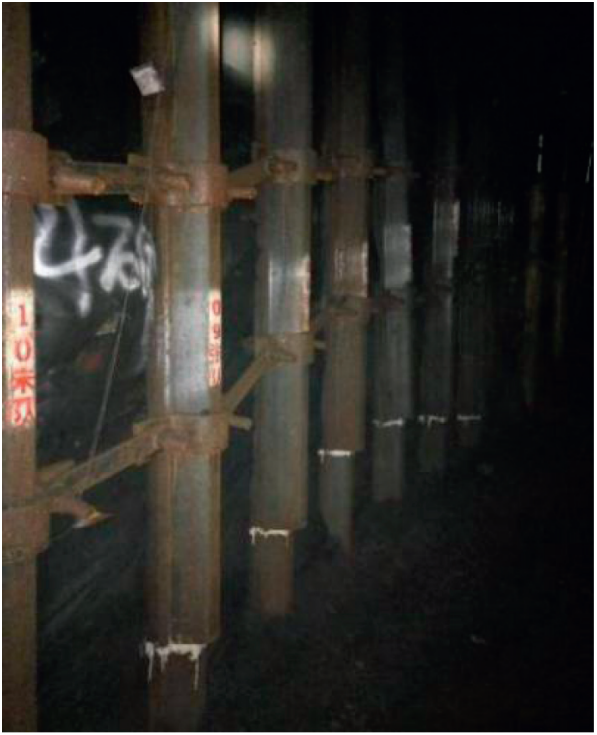

FIGURE 14: Effect diagram of nonpillar gob-side entry retaining by roof cutting support.

$96 \mathrm{~m}$ behind the working face. The deformation of the roof and floor is the most severe in this range, and mine pressure behavior is evident. The roof and floor approach increases from $216 \mathrm{~mm}$ to $650 \mathrm{~mm}$. The deformation rate of roof and floor is small in the influence stage of roadway retaining by one mining, and the deformation rate is from $16 \mathrm{~mm}$ to $28 \mathrm{~mm}$ during severe deformation.

Under the condition of grading support in different stages, the maximum roof and floor movement of the II 632 transport gateway is stable at approximately $650 \mathrm{~mm}$. Through field photography, as shown in Figure 14, the stability of surrounding rock of roadway is good. According to statistics, the grading support method in different stages can meet the needs of safety production of working face and also achieve significant economic benefits.

\section{Conclusions}

(1) Through the three-dimensional physical simulation experiment, the following results are obtained. In the dip direction, vertical microcracks appear at the overburden cutting joints; when the basic roof collapse and fall, the overlying strata of the roadway and the strata on the side of the goaf form a relatively stable hinge key block structure. In the strike direction, the caving layers gradually increase; the horizontal roof caving strata are hinged with each other to form a stable masonry structure.

(2) The deformation monitoring of the roadway surrounding rock indicates that the roof of the roadway deformation is skewed, the roof subsidence near the goaf is greater than that of the coal pillar side, and the roof subsidence is greater than the floor heave and the two sides approach. The roof of the roadway stress reaches the peak when it is approximately $20 \mathrm{~m}$ away from the working face, and the distance of the lagging working face affected by one-time mining is from $20 \mathrm{~m}$ to $60 \mathrm{~m}$.

(3) Through a similar simulation experiment, the stable hinged key block structure is formed after the basic roof of the overburden is broken. By constructing the mechanical model of the hinged key block structure, the mechanical analytical solution of the retaining roadway roof support resistance is obtained. 
Combined with the actual geological conditions of the Hengyuan coal mine II 632 and the constant resistance and large deformation anchor cable proposed, the method of roof reinforcement and support effectively controls the deformation of the retained roadway roof.

(4) According to the field measurement, the maximum subsidence of the roof of the retained roadway roof is approximately $360 \mathrm{~mm}$, the maximum floor heave of the floor of retained roadway is approximately $290 \mathrm{~mm}$, and the retained roadway without coal pillar is between the canceled working faces; moreover, it can meet the use requirements of the next mining face.

\section{Data Availability}

The data used in the field measurement can be obtained from the corresponding author upon request.

\section{Conflicts of Interest}

The authors declare no potential conflicts of interest with respect to the research, authorship, and/or publication of this article.

\section{Acknowledgments}

The authors acknowledge the financial support for this work provided by the National Natural Science Foundation of China (grant no. 51774010).

\section{References}

[1] X. Liu, X. Z. Hua, P. Yang, and Z. Huang, "A study of the mechanical structure of the direct roof during the whole process of non-pillar gob-side entry retaining by roof cutting," Energy Exploration \& Exploitation, vol. 38, no. 5, pp. 17061724, 2020.

[2] M. Wang and J. B. Bai, "Failure mechanism and control of deep gob-side entry," Arabian Journal of Geosciences, vol. 8, no. 11, pp. 9117-9131, 2015.

[3] Y. B. Gao, Z. B. Guo, J. Yang, and J. Wang, "Steady analysis of gob-side entry retaining formed by roof fracturing and control techniques by optimizing mine pressure," Journal of China Coal Society, vol. 42, no. 7, pp. 1672-1681, 2017.

[4] G. H. Yang, K. Wang, and X. Q. Zhang, "Study on non-pillar mining technology of preset packing body and roof cutting in deep well roadway," Journal of Mining and Strata Control Engineering, vol. 2, no. 1, pp. 67-74, 2020.

[5] B. Yu, J. X. Yang, C. Y. Liu et al., "Overburden structure and mechanism of rock pressure in large spacestope," Journal of China Coal Society, vol. 44, no. 11, pp. 3295-3307, 2019.

[6] J. X. Yang, C. Y. Liu, B. Yu, and Y. Lu, "Impact effect causedby the fracture of thick and hard roof structures in a longwall face," Journal of China University of Mining and Technology, vol. 43, no. 1, pp. 8-15, 2014.

[7] H. P. Kang, G. Xu, B. M. Wang et al., "Forty years development and prospects of underground coal mining and strata control technologies in China," Journal of Mining and Strata Control Engineering, vol. 1, no. 2, pp. 7-39, 2019.
[8] G. F. Zhang, P. P. Miao, E. Y. Wang, and X. Chen, "Research on roof fracture criterion and moving rule of gob-side entry in shallow seam," Journal of Mining Science and Technology, vol. 2, no. 2, pp. 109-119, 2017.

[9] C. Su, P. L. Gong, H. P. Kang et al., "Mechanism of roof cutting and pressure relief in gob-side and high-stress roadway in deep coal mine," Journal of Mining \& Safety Engineering, vol. 37, no. 6, pp. 1104-1113, 2020.

[10] J. Wang, R. Gao, G. Y. Yu et al., "Experimental study on infrared radiation characteristics of overburden movement of self-forming roadway under pressure relief," Journal of China Coal Society, vol. 45, pp. 119-127, 2020.

[11] Y. Zhang, F. X. Shen, X. M. Sun et al., "Stress and deformation law of surrounding rock in the second reuse of roadway formed by roof cutting in the "three soft" coal seam," Journal of China University of Mining \& Technology, vol. 42, no. 9, pp. 247-254, 2020.

[12] X. G. Ma and M. C. He, "Deformation mechanism and control measures of overlying strata with gob-side entry retaining for med by roof cutting and pressure releasing," Journal of China University of Mining \& Technology, vol. 48, no. 3, pp. 474-483, 2019.

[13] M. C. He, X. G. Ma, and B. Yu, “Analysis of strata behavior process characteristics of gob-side entry retaining with roof cutting and pressure releasing based on composite roof structure," Shock and Vibration, vol. 2019, Article ID 2380342, 12 pages, 2019.

[14] X. J. Yang, C. W. Hu, M. He et al., "Study on presplitting blasting the roof strata of adjacent roadway to control roadway deformation," Shock and Vibration, vol. 2019, Article ID 3174898, 16 pages, 2019.

[15] X. Z. Hua, X. Liu, Z. G. Huang et al., "Stability mechanism of non-pillar gob-side entry retaining by roof cutting under the coupled static-dynamic loading," Journal of China Coal Society, vol. 45, no. 11, pp. 3696-3708, 2020.

[16] J. Yang, Q. Fu, Y. B. Gao et al., "Research on roof deformation laws and mechanism in a non-pillar mining method with entry automatically formed during the whole cycle," Journal of China Coal Society, vol. 45, no. s1, pp. 87-98, 2020.

[17] Y. J. Wang, M. C. He, K. X. Zhang, and J. Yang, "Strata behavior characteristics and control countermeasures for the gateroad surroundings in innovative non-pillar mining method with gateroad formed automatically," Journal of Mining \& Safety Engineering, vol. 35, no. 4, pp. 677-685, 2018.

[18] N. Zhang and C. L. Han, "Theory and practice of surrounding rock control for pillar less gob-side entry retaining," Journal of China Coal Society, vol. 39, no. 8, pp. 1635-1641, 2014.

[19] X. G. Ma and M. C. He, "Entry deformation law in the full life cycle under entry retaining with roof cutting," Geotechnical \& Geological Engineering, vol. 37, no. 5, pp. 4365-4379, 2019.

[20] B. J. Sun, X. Z. Hua, Y. Zhang et al., "Analysis of roof deformation mechanism and control measures with roof cutting and pressure releasing in gob-side entry retaining," Shock and Vibration, vol. 2021, no. 11, 13 pages, Article ID 6677407, 2021.

[21] Q. Sun and J. X. Zhang, "Failure mechanism and deformation characteristics of gob-side entry retaining in solid backfill mining: a case study," Natural Resources Research, vol. 2, 2019.

[22] Q. Wang, M. C. He, and J. Yang, "Study of a no-pillar mining technique with automatically formed gob-side entry retaining for long wall mining in coal mines," International Journal of Rock Mechanics and Mining Sciences, vol. 110, pp. 1-8, 2018.

[23] Z. B. Guo, J. Wang, T. P. Cao et al., "Research on key parameters of gob-side entry retaining automatically formed by 
roof cutting and pressure release in thin coal seam mining," Journal of China University of Mining and Technology, vol. 45, no. 5, pp. 879-885, 2016.

[24] P. F. Guo, M. C. He, J. Wang, and H. Zhou, “Test study on multi tray bolt in gob-side entry retaining formed by roof cut and pressure releasing," Geotechnical \& Geological Engineering, vol. 35, no. 7, pp. 1-10, 2017.

[25] X. M. Sun, X. Liu, G. F. Liang et al., "Key Parameters of gobside entry retaining formed by roof cut and pressure releasing in thin coal seams," Chinese Journal of Rock Mechanics and Engineering, vol. 33, no. 7, pp. 1449-1456, 2014.

[26] S. Y. Chen, M. C. He, H. J. Wang et al., "Coordination control and stress evolution of surrounding rock of gob-side entry retaining cutting roof in deep mine," Journal of Mining \& Safety Engineering, vol. 36, no. 4, pp. 660-669, 2019.

[27] C. F. Yuan, Y. Yuan, C. Zhu et al., "Reasonable parameters of roof cutting entry retaining in thin immediate roof and large mining height fully-mechanized face," Journal of China Coal Society, vol. 44, no. 7, pp. 1981-1990, 2019.

[28] Y. F. Li and X. Z. Hua, "Mechanical analysis of stability of key blocks of overlying strata for gob-side entry retaining and calculating width of roadside backfill," Rock and Soil Mechanics, vol. 33, no. 4, pp. 1134-1140, 2012.

[29] C. J. Hou and N. J. Ma, "Stress in in-seam roadway sides and limit equilibrium zone," Journal of China Coal Society, vol. 4, pp. 21-29, 1989. 